\title{
2
}

\section{Stigmatising Gang Narratives, Housing, and the Social Policing of Mãori Women}

\author{
Cassandra Lewis, Adele N. Norris, \\ Waimirirangi Heta-Cooper, and Juan Tauri
}

\section{Introduction}

Internationally, including in New Zealand, homelessness, evictions, and foreclosures are commonplace and even the hallmark of many cities and small towns struggling to survive (Eaqub \& Eaqub, 2015; Madden \& Marcuse, 2016; McNeill, 2016). The United Nations estimates that the homeless population, depending on how homelessness is defined, could be anywhere between 100 million to one billion people across the world (Madden \& Marcuse, 2016). Increasingly, discussions of rising housing prices and cost of living dominate mainstream media and political discourses (Eaqub \& Eaqub, 2015; Madden \& Marcuse, 2016; McNeill, 2016; Munro, 2018). After the 2008 global economic meltdown, the term 'housing crises' emerged, drawing attention from reformers, activists, and academics. The global housing crises have gained considerable

C. Lewis $\bullet$ A. N. Norris $(\bowtie) \bullet$ W. Heta-Cooper $\bullet J$. Tauri

University of Waikato, Hamilton, New Zealand

e-mail: adele.norris@waikato.ac.nz; jtauri@waikato.ac.nz 
traction over the last decade, prompting new national conversations. However, the idea of 'crisis' implies that inadequate or unaffordable housing is abnormal, a temporary departure from a well-functioning standard. For Indigenous, Black, and working-class people and communities, the housing crisis is often the norm (Alexander, 2012; Madden \& Marcuse, 2016; Proulx, 2018; Ross, 1998; Smith, 2015; Walker, 2004).

Over-crowded and unhealthy dwellings have always persisted for the oppressed and the dispossessed (Hemmons, 1996; Madden \& Marcuse, 2016; Moreton-Robinson, 2015; Ross, 1998; Smith, 2015; Walker, 2002, 2004). Controlling one's housing is a way to control one's labour, free time, relationships/friendships, schools, and so on. Struggles over housing are always, in part, struggles over autonomy and selfdetermination (Madden \& Marcuse, 2016). Where one lives can precisely influence the treatment one receives by the state and wider society (Banivanua Mar, 2016; Bledsoe \& Wright, 2019; Bonilla-Silva, 2000; Hattery \& Smith, 2018; Ross, 1998; Smith, 2015). As it is widely known that residential oppression has been shaped by historical policies of exclusion and racialised social control, it is not experienced uniformly (Bledsoe \& Wright, 2019; Madden \& Marcuse, 2016; Ross, 1998; Smith, 2015). Thus, the contemporary housing crisis cannot be untangled from the legacy of exploitative historical events, such as colonisation.

Considerable scholarship on housing-related issues has increased globally over the past decade. Important to this discussion is the renewed attention towards housing as an essential race-making institution and its connection to the carceral state (Bonds, 2019; Inwood \& Bonds, 2017). Little work has been undertaken using critical discourse analysis (CDA) to examine housing political discourse as it relates to the presence of stigmatising narratives used to criminalise different segments of the population, especially Indigenous people. This chapter sets the context for a CDA of this issue by first providing a brief overview of the historical and contemporary processes that set in motion unequal or restricted access to housing. The focus then shifts to a discussion of the interrelated nature of stigmatising narratives, social policing, and discriminatory housing practices. The findings section presents three key framing techniques. This chapter concludes with a discussion of particularly powerful and salient elements of the language used to frame tenants and housing issues that 
likely impede or restrict access to housing, especially for Indigenous women living precarious lives.

\section{Power Relationships, Māori, and Housing}

In New Zealand, the housing system intersects with stratification and exclusion in complicated ways that are rooted in modern capitalism, racial control, setter-colonialism, and White supremacy. For example, the Settler Wars of the 1860s led to massive Māori (Indigenous New Zealander) land appropriation. The Pākehā (New Zealander of European descent) hegemony facilitated the enactment of a privatisation policy and numerous land laws that created 'a legal jungle within which Māori lost themselves and were preyed on by its natural denizens, the land speculators or their agents and shyster lawyers' (Sinclair, 1980; as cited in BonillaSilva, 2000, p. 201). At the end of the nineteenth century, the New Zealand government introduced a series of educational and political reforms to accelerate the civilization process of Māori, but the underlying intent was to normalise their supremacy over Māori land and its people (Banivanua Mar, 2016; Bonilla-Silva, 2000). Massive land appropriation continued into the twentieth century. Regardless of increased urbanisation and the concomitant social advancements policymakers believed would accrue (see The Hunn Report, 1961), by the mid-1960s many Māori communities began to exhibit precarious social indices characteristic of increased contact with institutions of social control (Tauri, 2016) and engagement in low wage sectors of the labour market (O'Sullivan, 1999). The advent of neo-liberal social and economic policy by the third Labour government in the 1980s saw Māori over-representation in negative social statistics across a range of policy portfolios solidify, especially in relation to crime and victimisation, child care and protection contacts, low educational attainment, and a range of housing-related issues such as home ownership and homelessness (Marriott \& Sim, 2015).

Groot, Hodgetts, Nikora, and Leggatt-Cook (2011) identify homelessness as a common theme experienced by Indigenous people worldwide and specific to New Zealand. The authors link the over-representation of Māori homelessness to the colonial project of propelling a significant 
number of Māori into impoverished and over-crowded urban housing plans in the immediate post-war era. It is also worth noting that Māori were once favoured in government social housing policies (Walker, 2004; Wanhalla, 2006) as colonial initiatives encouraged the urbanisation of Māori to hasten their assimilation into Western ideals of the consumercitizen (Woods, 2002). It is documented that this 'privilege' soon changed. By the 1970s and throughout the 1980s, Māori began experiencing racialised obstructions and restrictions in attaining social housing (Murphy \& Cloher, 1995).

Māori over-representation in working-class jobs and severe underrepresentation in professional and managerial employment (BonillaSilva, 2000) automatically place them in a precarious position to secure housing. Neo-liberal reform of the welfare state and privatisation of social housing during the 1990s-2000s further compound the issue as stateowned housing stock quickly depleted and social housing was reconfigured at market rates (Wanhalla, 2006). Māori families engaged in precarious work/employment have continuously experienced scrutiny of race-based policing that has resulted in extreme marginalisation. Poor single mothers, often stereotyped as the 'undeserving poor', were particularly vulnerable to being locked out of secure housing (Kingfisher, 1999).

Power relationships between existing class structure and society hinge on housing (Madden \& Marcuse, 2016). Given this, housing has always been a central mechanism used for racial social control and race-based policing and is thus inseparable from the criminalisation of Indigenous people (Alexander, 2012; Andrai, McIntosh, \& Coster, 2017; Ritchie, 2017; Ross, 1998; Smith, 2015). US scholars have long examined statecondoned violence against Black and Brown people, interrogating the relationship between housing and crime-control policies (Alexander, 2012; Bledsoe \& Wright, 2019; Davis, 1997; Norris \& Billings, 2017; Provine, 2007; Roberts, 1993; Ross, 1998; Smith, 2015). While colonisation occurred differently across nation states, similarities exist among Indigenous peoples, including their experience of criminalisation, of them as individuals, of their communities, and their cultural practices (Cunneen \& Tauri, 2016). Since the 1980s, housing and race have been central themes in the narrative around the War on Drugs and gangs in both the United States and New Zealand (Alexander, 2012; Andrai et al., 
2017; Hattery \& Smith, 2018; Norris \& Billings, 2017; Ritchie, 2017; Ross, 1998). Locating crime and gang activity in urban areas, inner cities, ghettos, housing projects, or rural areas with high minority populations have been a consistent strategy among policymakers, police, and mainstream criminology (Alexander, 2012; Bledsoe \& Wright, 2019; Norris $\&$ Billings, 2017). Residents from these areas, regardless of their disposition, are vulnerable to labels of being deviants, gang members, violent, or morally corrupt. Factors driving high rates of imprisonment among Indigenous people, to the extent that they have become the most incarcerated group of people in the world (Cunneen \& Tauri, 2016), also influence Indigenous people's access to housing and proximity to the criminal justice system.

\section{Stigmas, Social Policing, Housing Discrimination}

Policy issues are defined in a multitude of ways. Often policymakers rely on story lines that emphasise one aspect of an issue over others, which influences the appearance of social problems on the public agenda (Goetz, 2008). Framing, given its influential nature in determining policy alternatives, policy outcomes, and the connection between a problem and solutions (Goetz, 2008), has been discussed broadly within housingrelated discourse. For example, Edward Goetz's (2016) examination of the framing of affordable housing in the Twin Cities of Minneapolis and Saint Paul, Minnesota, found that social housing advocacy groups struggle with conveying the critical need for affordable housing to both policymakers and communities. Challenges mostly arise from deeply rooted stigmas attached to poverty and the 'racial other'. Goetz (2016) notes that advocates for the poor, as well as public officials responsible for affordable housing programmes, are met immediately with negative reactions that range from not-in-my-back-yard responses to offering stigma-laden narratives of low-income people that conjure images of crime, social decay, and alcohol/drug abuse. 
To encourage suburban communities to provide a full range of housing options, advocates navigate hostility by depicting beneficiaries as White, employed in widely accepted jobs (such as teachers, police officers, firefighters, nurses, and nurses' aides) and with young families (Goetz, 2016). Strategies also include the use of senior citizens as beneficiaries. The study found that substituting the language from affordable housing, which conjured imagery of the racial other, poverty, and crime, to lifecycle housing produced significantly different results wherein the latter received stronger support. Such strategies are very telling in that they reveal the embedded nature of the association of affordable housing with the 'racial other'; in this case, Black, Indigenous peoples, and Latino populations (Hanson, Hawley, \& Taylor, 2011; Hattery \& Smith, 2018). This study also illustrates how deeply rooted stigmas attached to non-White populations give rise to various types of social policing even before one enters the housing market.

Social policing often refers to the use of the police force to control the behaviour of Black and Brown people (e.g., by arrest, incarceration, murder, etc.). The term also means the control, regulation, and surveillance of Black bodies in terms of how Black people are allowed to be, where they are allowed to go and when, and what choices Black people are allowed to make (Hattery \& Smith, 2018). The complex nature of the social policing of Black and Brown bodies has always been a prominent feature in housing discussions and policy (Hattery \& Smith, 2018; Madden \& Marcuse, 2016; Ross, 1998). In a country like the United States, property has always been intertwined with race. Anti-black racism, First Nation genocide, and White supremacy were foundational to the housing system.

Symbolic policing, particularly in the case of housing, refers to an aspect of policing that does not involve either law enforcement or the criminal justice system (Hattery \& Smith, 2018). The term symbolic policing denotes strategies of surveillance and control extending far beyond 'the police' and involves state agencies and agents across a range of policy portfolios, including social security, labour market and employment, childcare and protection, and housing. Groups relegated to segregated communities or excluded from securing housing, despite having the resources to pay, experience a type of social restriction of movement 
via a variety of systems and policies (Bledsoe $\&$ Wright, 2019; BonillaSilva, 2006). For example, today in the United States, Black people are denied available housing 35-75\% of the time (Bonilla-Silva, 2006). Discrimination in US states with large First Nation populations is even higher. Discrimination against Indigenous renters ranges from $25.7 \%$ in New Mexico to 33.3\% in Minnesota, averaging 28.5\% across the states (Turner \& Ross, 2003). Minorities are less likely to be shown apartments as their White counterparts; are quoted higher rents; experience worse housing conditions; and are more likely to be steered to specific (nonWhite, affluent) neighbourhoods (Bonilla-Silva, 2006). Housing, social policing, and symbolic policing intersect in complex ways. Communities with high populations of Black and Brown people are over-policed and experience rampant state-sanctioned violence (Alexander, 2012; Proulx, 2018; Ritchie, 2017).

However, racial discrimination and housing are far from new discussions. A violence birthed in the establishments of colonisation and slavery was not only a process of dehumanisation, but also the genesis of the creation of cultural stereotypes that continue to undermine, control, and restrict marginalised peoples (hooks, 1981; Norris \& Billings, 2017; Ritchie, 2017; Ross, 1998; Smith, 2015). Because it is illegal, today, to outright deny housing based on race, it is imperative to interrogate contemporary forms of more covert racist practices that structures risk, choices, and life chances.

Eduardo Bonilla-Silva's (2015) examination of the structure of new racism in the United States, during a time of a so-called colour-blind and post-racial era, looks at housing and the economy. Housing and residential segregation, nowadays, is almost as pronounced as in the past (Bledsoe \& Wright, 2019; Bonds, 2019; Massey \& Denton, 1993) even though some of the contemporary forms of segregation are not even captured by the indices used (Bonilla-Silva, 2015). Bonilla-Silva (2015) notes that:

[S] egregation persists because discrimination in the housing and lending markets remains. Blacks and Latinos experience discrimination in forms such as steering by realtors, receiving a disproportional number of subprime loans net of their credit worthiness, and being given differential information about the availability of housing units. These practices 
illustrate new style discrimination because all of them are hard to detect and even harder to label "racial." We know about all of them mostly because of audit studies and not due to reports from the victims of discrimination. In fact, most of the minority participants in these studies did not even realise they had experienced discrimination until they compared notes with their White counterparts. (p. 1362)

Bonilla-Silva (2015) illustrates that the steering practices listed above are not only legal but are also difficult to detect. Even those who are victims of steering practices are oblivious to the racist intent.

While extensive research in the area of housing screening practices and discrimination is emerging in New Zealand, several cases exist detailing similar occurrences of discrimination in accessing social housing. Housing, like in many other countries, is on the government agenda in New Zealand and is widely discussed in mainstream media. Specific cases of steering practices and discrimination do not receive the same attention as housing affordability and the rising rate of homeless. For example, in November 2018, the Bay of Plenty Times met with Donna Love, a 34-year-old single mother, to report how she was squeezed out of Tauranga's rental market because of her number of children. Comments from emergency housing advocates not only substantiated Donna's claims but also confirmed that she is one of many being discriminated against by selective landlords ('Tauranga mum', 2018). Despite having good references, a full bond, and a good credit history, Donna was told she did not fit the criteria, yet the requirements were never specified. As a result, Donna moved her children into a tent in her mum's backyard for a couple of nights. Donna explained that her decision to move to Tauranga was to be near her mum to receive help with her children.

A few months later, also in Tauranga, Reremai Cameron, a Māori woman, felt dehumanised in her search for housing. Inquiring about a listing of a single room she found on Trade Me, Reremai stated that the potential landlord asked in one text message, 'Just reading your name, are you Māori? If so I hope you are aware the rent would only cover you and no friends or family to stay in the sleep out. We had a Māori in our home before who had multiple family and friend visitors that is something we 
will not tolerate' (Bell, 2019). Both cases provide insight into specific ways race, gender, and class play out in housing screening practices and the power dynamics of securing housing in general.

\section{The Criminalisation of Indigenous Peoples and Housing}

Indigenous people have the highest rates of incarceration in the world (Cunneen \& Tauri, 2017; McIntosh \& Workman, 2017). Roughly 15\% of New Zealand's total population is Māori, which also comprises over half of the country's prison population (Cunneen \& Tauri, 2017; Deckert, 2014). Māori women are the highest incarcerated group, making up $62 \%$ of the female prison population and $57 \%$ of women on community sentences (Bevan \& Wehipeihana, 2015). Mechanisms influencing Māori women's rate of imprisonment undoubtedly influence their access to housing.

It is important, therefore, to emphasise the historical criminalisation of Indigenous peoples (Agozino, 2018; Kitossa, 2012; Ross, 1998; Smith, 2015; Tauri, 2014; Walker, 2002). Indigenous and Black scholars have identified specific ways stereotypes and the creation of controlling images have permeated mainstream discourses and societal perceptions so much so that race or ethnicity do not have to be identified for one to conjure the image of the 'racial other' as criminal and/or violent (Bull, 2017; Collins, 2004; hooks, 1981; Norris \& Billings, 2017; Ritchie, 2017; Ross, 1998; Welch, 2007). Ample research exists detailing specific ideological and political tactics employed at all levels of society to criminalise Black and Indigenous peoples while at the same time excluding or exonerating White people from criminalising and deficit narratives (Alexander, 2012; Norris \& Billings, 2017; Norris \& Lipsey, 2018; Quince, 2017; Walker, 2002).

Social housing, in particular, has remained a site for the regulation of tenants' behaviour (McNeill, 2016). Historically marginalised people have always been relegated to social housing in some form-locked out of education, housing, and economic markets-thus, vulnerable to 
stereotypes, social policing, and criminalisation (Bonilla-Silva, 2000; McNeill, 2016; Norris \& Billings, 2017; Proulx, 2018; Ross, 1998; Shilliam, 2015). It is well established that negative stigmas are used to dehumanise and to limit, restrict, and deny assistance to the poor, especially poor single mothers. While Indigenous scholars have examined racial social control especially with regard to gangs, how the stigma of gang affiliation influences access to quality housing has not received scholarly attention. As housing is a key issue on the government agenda, the process by which property speculators, landlords, and rental agents screen potential tenants based on preconceived characteristics is of critical importance and is under-researched. The framing of 'gangs' and individuals perceived as 'gang affiliates' in housing discourse likely influence the general perceptions of the 'good' versus the 'bad' tenant. Because social housing policies are set and implemented at the national, regional, and local levels and influenced by private, public, and non-profit realms, as well as by liberals and conservatives, political rhetoric can lend itself to providing insight into housing screening practices. Employing a critical discourse analysis to examine parliamentary debates (Hansard) about the Organised Crime Bill and Residential Tenancies Bill from 2009-2018, this project examines how gangs enter and are framed in housing-related political discourse.

\section{Methodology}

Hansard is the official record of the New Zealand parliament that includes debates and events on the floor of the House. It is the 'verbatim record' of debates being reported in direct speech (Slembrouck, 1992). In order to explore the socio-political-cultural context in which discussions of crime and housing occur, an examination of Hansard parliamentary debates was deemed ideal. This space allows for an interrogation of the relationship between language use and ideology to get a sense of power, control, conflict, and dominance. In doing so, one also gains an idea of the distribution of social and physical resources.

To examine how gangs enter and are framed in housing-related political discourse, New Zealand's parliamentary database (accessed through 
www.parliament.nz/en/) was consulted. After filtering for Hansard speeches, the Organised Crime Bill (two readings) and Residential Tenancy Amendment Bill (three readings) were retrieved. Given the aim to uncover the language around organised crime, a content analysis was deemed most appropriate. Keywords and phrases related to 'criminal activity', 'threat', and 'violence' provided the initial set of codes. From this point, emergent themes and subthemes were identified. The codes and themes identified in the Organised Crime Bill then served as the initial codes for the second component of the study, which examined the Residential Tenancy Bill.

\section{Findings}

In this section, we discuss the emergent themes from analysis of parliamentary speeches, as recorded in Hansard, starting with the Gangs and Organised Crime Bill, followed by consideration of statements related to the Residential Tenancy Amendment Bill.

\section{Gangs and the Organised Crime Bill}

The first component of the analysis examined two readings from the Organised Crime Bill in 2009, consisting of 38 speeches and 25,940 words in total. The keywords gang(s), criminal, corporate companies/ corporations, white-collar crime/criminals, Māori, and Pākehā/European/ White were part of the initial search. From this stage, subthemes emerged such as political parties and iwi (tribes). For example, while political parties/groups and companies/corporations were never singled out as participants in organised crimes, one iwi in particular, Tuhoe, emerged via speeches as a distinct threat to community safety. More specifically, Tuhoe's political activism was conflated with gang activity, thus violent. Strategically linking Tuhoe with gang-like behaviour justified their need for suppression. The framing of Tuhoe as 'violent', and behaviour of its members as 'gang like' and requiring suppression, needs to be analysed within the context of the 'terror raids' carried out by New Zealand Police 
in October 2007. Ostensibly undertaken due to supposed 'terrorism-like' conduct by members of Tuhoe, armed police descended on Tuhoe lands and arrested eight individuals who were charged under the Suppression of Terrorism Act 2002 (Sluka, 2010). Despite the fact that the terrorismrelated charges were eventually dismissed, the Tuhoe were subsequently problematised in discourse related to the Bill. Corporate crime' only surfaced once to introduce corporate crime into the discussion, but the rhetoric immediately shifted to gangs and/or gang activity. "White collar crime' received very little attention being mentioned only three times. Conversely, 'gang(s)' emerged 363 times, which was almost exclusively associated with 'Māori', which emerged 157 times.

'Pākehā/European/White' received hardly any references and only emerged indirectly from one speaker with six references to the Hells Angels (a predominately Pākehā/White gang). Given this, 'gangs', 'Māori', and 'crime/criminal activity' emerged as primary themes and were discussed relationally. Police emerged as a secondary theme given their proximity to gangs/gang activity. Mentioned 157 times, police were brought into the discussion only in association with an expansion of gang surveillance. 'Youth' and 'violent crime' also surfaced as secondary themes linked to gang activity. The former was discussed in terms of being perpetrators of violent crimes as gang members and also susceptible to gang affiliation if not given the proper intervention. The latter, 'violent crime', was linked only to gang activity. Thus, eradicating violent crime meant eradicating gangs.

\section{Residential Tenancy Amendment Bill}

Emergent themes from the Gangs and Organised Crime Bill served as the initial codes used to examine parliamentary speeches about the Residential Tenancy Amendment Bill (2009-2016), which consisted of three readings and 57,800 words. Significant attention was devoted to the housing crises that gave rise to a myriad of social problems in its wake. Keywords such as 'rentals/rental property' surfaced 205 times, mostly when articulating unaffordability, inefficient housing, and excessive power bills. Affordability of heating residential houses emerged in association with 
poverty, illnesses, and children. While secondary, gangs emerged in a similar fashion as found in the Gangs and Organised Crime Bill. Gang(s) specifically emerged in the discussion of state housing, violence/destruction, Māori, low-income, and locations with high minority populations (e.g., South Auckland, Manukau East, Mangere, Porirua, and Otara). These discussions also centred women as victims of gang violence or as gang associates with the potential to introduce criminal activity into housing. White/Pākehā/European never emerged. Violence and destruction of property were associated primarily with Māori and only occurring in low-income areas. Drug use emerged but only in reference to gang activity and low-income pockets/neighbourhoods. These rhetorical tactics worked to exonerate Pākehā/European/White and middle-class populations from deviant labels, violent activity, and crime and drug use. Through the process of omission, the White middle-class population is constructed as the 'ideal' or 'good' tenant.

\section{Discussion}

Through processes similar to what Schneider and Ingram (1993) detail as social construction of target populations, gangs were used to frame racial/ ethnic groups as 'good' or 'bad' tenants. For example, the blatant omission of Pākehā/Europeans/White exonerates the dominant racial/ethnic group from association with crime, gang activity, and violence. Pākehā are, thus, excluded from stigmatising narratives, which in turn, influence access to housing, even when they are associated and engaged with criminal activity. Through this omission, Pākehā assumed a default position within the legislative and policy context of 'government' as morally superior and 'worthy' (of state assistance and support). Moreover, this process also constructed Pākehā as the group in need of protection with the power to precisely define from whom and what they need protection from (e.g., Māori and gangs). In this case, gangs (more precisely, Māori gangs) are presented as a threat to the broader social order.

Similarly, white-collar crime and political organisations were excluded from the discussion of criminality and criminal activity. Concealing white-collar criminal activity from public scrutiny, political and public 
discourses offer a type of protectionism that undoubtedly intersects with race (White) and social class (upper-middle class). Techniques used to frame organised crime or criminal activity centred Māori by relying heavily on individual accounts, sensationalised by political actors and racially dominant groups, which Harrison and Sanders (2016) identify as poignant strategies that successfully frame the 'irresponsible poor', the 'failing family', or the deviant perpetrators of riotous acts. Groups falling into the 'undeserving' category are particularly vulnerable to facing socioeconomic disadvantages, media condemnation, and declining public sector support, which often leads to a 'downward spiral of condition[s] and process[es] of what might be called relative dispossession' (Harrison \& Sanders, 2016, p. 9).

In their discussion of drivers of popular support for increased social control of low-income and minority racial groups, Harrison and Sanders (2016) emphasise unbalanced press reporting that plays upon, rather than discourages, negative perceptions of 'less-deserving' people, which, in turn, strengthens fear and intra-class or intra-group hostilities:

In this context, ideas about misbehaviour appear to overlap with concepts of the underserving, and it is difficult to separate hostile perceptions of behavioural, 'characteristics' from assumptions linked to intra-class demarcations, ethnicity, gender, disability and other differentiations. (p. 7)

Very much like Goetz's (2008) analysis of the framing of affordable housing in the Twin Cities of Minneapolis and Saint Paul, Minnesota, our research demonstrates the often nefarious nature of the process through which policy and legislation are developed in New Zealand's Parliament. Legislation and policy resulting from the framing exercises of government can and does impact people's lives, sometimes in negative ways. The framing exercises associated with the Organised Crime and Residential Tenancy Bill's highlight a number of significant issues for those working to alleviate the precarious lives lived by many Māori, especially Māori women. Many of these issues align with Goetz's findings, including the dominance of policy discussion by politicians wedded to their Party's ideological constructions of social problems, which also aligned with the silencing of 'the Other'. In the case of this study, the deployment 
of rhetorical devices, via the use of gangs and gang members, were aimed at the criminalisation of Māori, and their negative representation as 'violent', 'bad tenants', and living in predominantly 'poor', deprived communities.

For Māori women, their framing in the parliamentary debates about both bills, centred on their 'associations' with gangs and gang members, especially as partners or ex-partners of gang members. The seemingly 'positive' rhetoric regarding Māori women's victimisation at the hands of gang members is tempered by their framing as a potential source of gangrelated issues for officials responsible for overseeing social housing. Those partnering with gang members were framed as potentially 'bringing crime in' to the social housing context through their intimate relations with male gang members, who were themselves framed as the violent, criminal brown men. But even those Māori women seeking social housing assistance as part of a strategy to escape relationships with gang members are equally framed as a potential source of crime and social disruption as a result of their 'previous (gang) association. This point highlights the power of the framing process, and of the master status conferred upon groups like Māori women that often results from it. The master status of "gang associate"' is a status that carries with it the potential to exacerbate (or create) barriers to accessing government assistance like social housing.

\section{Conclusion}

An examination of the framing of gangs in housing-related political discourse offers some insight into complex power dynamics driving relative dispossession with regard to restricted access to housing, which are difficult to detect. The way gangs are framed in the Organised Crime Bill racialised gangs as non-White through the use of coded language, colourblind strategies (e.g., naming towns/cities with large populations of Māori and Pacific Islanders and excluding Pākehā/European/White from crime-related discussions). These strategies worked in tandem to socially construct Māori as a threat warranting government intervention. Consequently, stigmatising narratives not only entered housing-related political rhetoric, but also set the stage for discussions of exclusionary 
practices. The Organised Crime Bill provided the foundation to socially construct Māori as the 'bad tenant' rendering them vulnerable to social policing and screening practices that possibly block access to social housing. While framing strategies, in the case of organised crime and criminal activity worked to conjure imagery of Māori and/or gangs in society's consciousness without explicitly mentioning either, the strategies also facilitated selectivity (e.g., target population) when extending criminalisation to a specific segment of the population (e.g., Māori).

Māori women are particularly susceptible to the stigmatising narrative of gang affiliation, especially if they reside in areas designated as gang territory, which are primarily associated with poor working-class communities and social housing. Because Māori women represent the highest group imprisoned, the status of 'ex-prisoner' will bear more harshly on Māori women, especially those with children, who will likely face obstacles to secure employment (Alexinas, 2008; Pool \& Baxendine, 2006). Therefore, it is imperative that the social ramifications of the growth of an imprisoned population and the consequence of high numbers of exprisoners are brought into contemporary discussions of housing and especially of access to social housing.

Through the use of controlling images or stigmatising narratives, Indigenous people are continuously surveilled and punished, not only by police but also by wider society (e.g., landlords and property speculators). Therefore, future research is needed to further expand the discussion regarding specific ways the stigma of gang affiliation transpires in the power dynamics between the landlords/rental agents and potential tenants to help identify particular forms of discrimination that hinder Māori, and especially Māori women from accessing social housing. Moreover, a critical examination of the tactics and strategies used to mask housing discriminatory practices will be useful to interrogate levels of deprivation experienced by certain segments of the population that likely influence their proximity to the criminal justice system. Lastly, it is imperative that research be carried out to identify strategies and tools marginalised people use to resist marginalisation tactics and rental screening practices. Centring the voices of those most affected is of paramount importance to inform public policy and academic enquiry. 


\section{Glossary}

Pākehā New Zealander of European descent.

Māori Indigenous New Zealander.

Tūhoe A Māori tribe of New Zealand.

Iwi Tribe, nation, extended kinship group and is often a large group of people descended from a common ancestor.

\section{References}

Agozino, B. (2018). The withering away of the law: An Indigenous perspective on the decolonisation of the criminal justice system and criminology. Journal of Global Indigeneity, 3(1), 1-24.

Alexander, M. (2012). The new Jim Crow: Mass incarceration in the age of colourblindness. New York, NY: New Press.

Alexinas, M. (2008). Working for better outcomes: An inquiry into the rehabilitation and reintegration of ex-offenders through integration in the labour market as a part of the criminal justice process. Unpublished Masters, University of Canterbury.

Andrai, D., McIntosh, T., \& Coster, S. (2017). Marginalised: An insider's view of the state. State policies in New Zealand and gang formation. Critical Criminology, 25, 119-135.

Banivanua Mar, T. (2016). Decolonisation and the Pacific: Indigenous globalisation and the ends of empire. Cambridge, UK: Cambridge University Press.

Bell, J. (2019, February 22). Tauranga women quizzed over Māori name disappointed by landlord prejudice. New Zealand Herald. Retrieved from https:// www.nzherald.co.nz/nz/news/article.cfm?c_id=1\&objectid=12205831

Bevan, M., \& Wehipeihana, N. (2015). Women's experiences of re-offending and rehabilitation. Wellington: Department of Corrections.

Bledsoe, A., \& Wright, W. J. (2019). The anti-Blackness of global capital. Environment and Planning D: Society and Space, 37(1), 8-26.

Bonds, A. (2019). Race and ethnicity I: Property, race, and the carceral state. Progress in Human Geography, 43(3), 574-583.

Bonilla-Silva, E. (2000). 'This is a white country': The racial ideology of the western nations of the world-system. Sociological Inquiry, 70(2), 188-214. 
Bonilla-Silva, E. (2006). Racism without racists: Colour-blind racism and the persistence of racial inequality in the United States (2nd ed.). Oxford, UK: Rowman \& Littlefield.

Bonilla-Silva, E. (2015). The structure of racism in color-blind, 'post-racial' America. American Behavioral Scientist, 59(11), 1358-1376.

Bull, S. (2017). Crime and Maori in the Media. In A. Deckert \& R. Sarre (Eds.), The Palgrave handbook of Australian and New Zealand criminology, crime and justice (pp. 737-768). Cham, Switzerland: Palgrave Macmillan.

Collins, P. H. (2004). Black sexual politics: African Americans, gender, and the new racism. New York, NY: Routledge.

Cunneen, C., \& Tauri, J. (2017). Indigenous criminology. Bristol, UK: Policy Press.

Davis, A. Y. (1997). Race and criminalization: Black Americans and the punishment industry. In L. Wahneema (Ed.), The house that race built (pp. 264-279). New York, NY: Random House.

Deckert, A. (2014). Neo-colonial criminology: Quantifying silence. African Journal of Criminology and Justice Studies, 8, 39-60.

Eaqub, S., \& Eaqub, S. (2015). Generation rent: Rethinking New Zealand's priorities. Wellington, NZ: Bridget Williams Books.

Goetz, E. G. (2008). Words matter: The importance of issue framing and the case of affordable housing. Journal of the American Planning Association, 74(2), 222-229.

Goetz, E. G. (2016). Resistance to social housing transformation. Cities, 100(57), 1-5.

Groot, S. A. M., Hodgetts, D., Nikora, L. W., \& Leggatt-Cook, C. (2011). A Māori homeless woman. Ethnography, 12(3), 375-397.

Hanson, A., Hawley, Z., \& Taylor, A. (2011). Subtle discrimination in the rental housing market: Evidence from e-mail correspondence with landlords. Journal of Housing Economics, 20(4), 276-284.

Harrison, M., \& Sanders, T. (Eds.). (2016). Social policies and social control: New perspectives on the 'not-so-big society'. Bristol, UK: Policy Press.

Hattery, A. J., \& Smith, E. (2018). Policing black bodies: How black lives are surveilled and how to work for change. Lanham, MD: Rowman \& Littlefield.

Hemmons, W. M. (1996). Black women in the new world order: Social justice and the African American female. Westport, CN: Praeger.

hooks, b. (1981). Ain't I a woman: Black women and feminism. Boston, MA: South End Press. 
Hunn, J. K. (1961). Report on Department of Mãori Affairs. Wellington: Government Printer.

Inwood, J. F. J., \& Bonds, A. (2017). Property and whiteness: The Oregon standoff and the contradictions of the U.S. Settler State. Space and Polity, 21(3), 253-268.

Kingfisher, C. P. (1999). Rhetoric of (female) savagery: Welfare reform in the United States and Aotearoa/New Zealand. NWSA Journal, 11, 1-20.

Kitossa, T. (2012). Criminology and colonialism: Counter colonial criminology and the Canadian context. The Journal of Pan African Studies, 4, 204-226.

Madden, D., \& Marcuse, P. (2016). In defense of housing. Brooklyn, NY: Verso. Marriott, L., \& Sim, D. (2015). Indicators of inequality for Maori and Pacific people. Journal of New Zealand Studies, 20, 24-50.

Massey, D., \& Denton, N. (1993). American apartheid. Cambridge, MA: Harvard University Press.

McIntosh, T., \& Workman, K. (2017). Māori and prison. In A. Deckert \& R. Sarre (Eds.), The Palgrave handbook of Australian and New Zealand criminology, crime and justice (pp. 725-736). Cham, Switzerland: Palgrave Macmillan.

McNeill, J. (2016). Regulating social housing: Expectation for behaviour of tenants. In M. Harrison \& T. Sanders (Eds.), Social policies and social control: New perspectives on the 'not-so-big society' (pp. 181-198). Bristol, UK: Policy Press.

Moreton-Robinson, A. (2015). The white possessive: Property, power, and Indigenous sovereignty. Minneapolis, MN: University of Minnesota Press.

Munro, A. (2018). Women, work and trade unions. London: Routledge.

Murphy, L., \& Cloher, D. (1995). Economic restructuring, housing policy and Maori housing in Northland, New Zealand. Geoforum, 26(4), 325-336.

Norris, A. N., \& Billings, J. (2017). Colorblind ideology, mass incarceration, and controlling racial images: An intersectional analysis of presidential rhetoric from 1969-1996. Journal of Ethnicity in Criminal Justice, 15(1), 79-98.

Norris, A. N., \& Lipsey, K. (2018). Public attitudes toward new prisons in New Zealand and deficit narratives: A quantitative survey. International Criminal Justice Review, Online First, 1-13. https://doi.org/10.1177/ 1057567718803147

O'Sullivan, D. (1999). Maori and the labour market: An analysis of Mantu Maori's Maori and work: The position of Maori in the New Zealand labour market. Hamilton: University of Waikato. 
Pool, I., \& Baxendine, S. (2006). Population trends, convictions and imprisonment: Demographic divergence, dichotomy and diversity. Population Studies Centre Discussion Paper No. 61, University of Waikato, Population Studies Centre, Hamilton Pool.

Proulx, C. (2018). White backlash against Indigenous peoples in Canada. The Canadian Journal of Native Studies, 38(1), 75-101.

Provine, D. M. (2007). Unequal under law race in the war on drugs. Chicago, IL: University of Chicago Press.

Quince, K. (2017). Rangatahi courts. In A. Deckert \& R. Sarre (Eds.), The Palgrave handbook of Australian and New Zealand criminology, crime and justice (pp. 711-724). Cham, Switzerland: Palgrave Macmillan.

Ritchie, A. J. (2017). Invisible no more: Police violence against Black women and women of color. Boston, MA: Beacon Press.

Roberts, D. E. (1993). Motherhood and crime. Iowa Law Review, 79, 95-141.

Ross, L. (1998). Inventing the savage: The social construction of Native American criminality. Austin, TX: University of Texas Press.

Schneider, A., \& Ingram, H. (1993). Social constructions and target populations: Implications for politics and policy. American Political Science Review, 87(3), 334-347.

Shilliam, R. (2015). The Black Pacific: Anti-colonial struggles and oceanic connections. London, UK: Bloomsbury.

Sinclair, K. (1980). A hisotry of New Zealand. Suffolk, England: Alle Lane.

Slembrouck, S. (1992). The parliamentary Hansard 'verbatim' report: The written construction of spoken discourse. Language and Literature, 1(2), 101-119.

Sluka, J. (2010). The Ruatoki Valley 'antiterrorism' police raids: Losing 'hearts and minds' in Ruatoki. Sites, 7(1), 44-64.

Smith, A. (2015). Conquest: Sexual violence and American Indian. Durham, NC: Duke University Press.

Tauranga mum of seven says she is being discriminated against by selective landlords. (2018, November 10). Bay of Plenty Times. Retrieved from https:// www.nzherald.co.nz/nz/news/article.cfm?c_id=1 \&objectid $=12153423$

Tauri, J. (2014). Criminal justice as a colonial project in settler-colonialism. African Journal of Criminology and Justice Studies, 8(1), 20-37.

Tauri, J. M. (2016). The state, the academy and Indigenous justice: A countercolonial critique. Doctoral thesis, University of Wollongong, Wollongong, Australia. Retrieved from https://ro.uow.edu.au/cgi/viewcontent. cgi? referer=https://www.google.com/\&httpsredir $=1 \&$ article $=5702 \&$ co ntext=theses 
Turner, M. A., \& Ross, S. L. (2003). Discrimination in metropolitan housing markets: Phase 3 - Native Americans. Working Paper prepared for Office of Policy Development and Research U.S. Department of Housing and Urban Development. Retrieved from https://www.huduser.gov/Publications/pdf/ hds_phase3_final.pdf

Walker, R. (2002). Maori news is bad news. In J. McGregor \& M. Comrie (Eds.), What's news? (pp. 215-232). Palmerston North, NZ: Dunmore Press.

Walker, R. (2004). Ka whawhai tonu matou: Struggle without end. North Shore, NZ: Penguin Books.

Wanhalla, A. (2006). Housing un/healthy bodies: Native housing surveys and Maori health in New Zealand, 1930-45. Health and History, 8(1), 100-120. Welch, K. (2007). Black criminal stereotypes and racial profiling. Journal of Contemporary Criminal Justice, 23(3), 276-288.

Woods, M. C. (2002). Integrating the nation: Gendering Maori urbanisation and integration, 1942-1969. Doctoral dissertation, University of Canterbury, Christchurch, New Zealand. Retrieved from https://ir.canterbury.ac.nz/ handle/10092/4352 